\title{
Counter Measures Criminal Act Of Narcotics
}

\author{
Mohammad Arief Amrullah', Revency Vania Rugebregt ${ }^{2}$ \\ ${ }^{1}$ Faculty of Law, Jember University \\ Jln. Kalimantan No. 37, Kampus Tegalboto, Jember, 68121, Indonesia \\ Tel.: +62-331-335462, 322808, Fax.: +62-331- 330482, 322809 \\ ${ }^{2}$ Faculty of Law, Pattimura University \\ Jln. Ir. M. Putuhena Kampus Poka, Ambon, 97233, Indonesia \\ Tel./fax: +62-911-3825204,_E-mail:revency_rugebregt@yahoo.com
}

\begin{abstract}
Narcotics crimes that are part of organized crime are essentially one of crimes against development and crimes against social welfare that are central to national and international concerns and concerns. It is very reasonable, given the scope and dimensions so vast, that its activities contain features as organized crime, white-collar crime, corporate crime, and transnational crime. In fact, by means of technology can be one form of cyber crime. Based on such characteristics, the impacts and casualties are also very wide for the development and welfare of the community. It can even weaken national resilience.
\end{abstract}

Keywords : narcotics; crime and countermeasures

\section{INTRODUCTION}

Crime is on the rise in various fields, both in terms of intensity and sophistication. Similarly, its threat to world security and hamper the progress of the country, both from the social, economic and cultural aspects. Given that evil develops according to the development of society, it is natural that there is an expression: evil is old in age, but young in the news. That is, from the first until now people are always talking about crimes, ranging from simple (ordinary crimes) to the evil that is difficult to prove.
The emergence of various forms of evil in a new dimension lately shows, evil is always evolving. Similarly, the crime of narcotics can not be separated from these developments. The drug trafficking industry is part of a group of activities of Transnational Criminal Organizations (ILOs) in addition to other types of crimes, namely, smuggling of illegal migrants, arms trafficking, trafficking in nuclear materials, transnational criminal organizations and terrorism, trafficking in 
body parts, theft and smuggling of vehicles, money laundering. ${ }^{1}$

These types of crimes are of grave concern to the international community, because if they are linked with threats or their consequences are so insidious, and can penetrate into various aspects or fields, both for national and international security and stability, and a major threat (frontal) attack) against political power, and a threat to the dignity of the state. The main purpose of this type of crime is to generate benefits for both individuals and groups who commit the crime. These illegal funds will be used by the perpetrator to fund subsequent criminal activities. $^{2}$

Narcotics crimes that are part of organized crime are essentially one of crimes against development and crimes against social welfare that are central to national and international concerns and concerns. It is very reasonable, given the scope and dimension so vast, so that its activities contain the characteristics as

1 UN Doc. E / CONF.88 / 2 dated August 18, 1994 and has been discussed in the World Ministerial Conference on Organizational Transnational Crime in Naples, 21-23 November 1994 with the Problem and Dangers Posed by Organized Transnational Crime in the Various Regions of the World The 9th UN Congress on the Prevention of Crime and the Treatment of Offenders in Cairo, 29 April - 8 May 1995, pg. 17-22

\footnotetext{
2 Ambassador Wendy Chamberlin, Principal Deputy Assistant Scretary, Bureau for International Narcotics and Law Enforcement Affairs, U.S. Department of State, in Economic Perspectives, The Fight Against Money Laundering.
}

organized crime, ${ }^{3}$ white-collar crime, corporate crime, white-collar crime, corporate crime, and transnational crime. In fact, by means of technology can be one form of cyber crime.

Based on such characteristics, the impacts and casualties are also very wide for the development and welfare of the community. It can even weaken national resilience.

Indonesia currently has Law no. 35 of 2009 on Narcotics (State Gazette of the Year 2009 Number: 143), dated October 12, 2009, which replaces Law no. 22 of 2007 concerning Narcotics (State Gazette Year 2007 Number 67), because as in the section weighing from Law no. 35 Year 2009 point e is stated: that Narcotics crime has been transnational conducted by using high modus operandi, advanced technology, supported by wide organization network, and has caused many victims, especially among the

3 To understand what constitutes an organized crime, in Article 2 paragraph 1 of the Proposal and Contributions Received from Governments, it is stated (General Assembly, A / AC.254 / 5 December 19, 1998), that the organized crime means activities which aim (act) in order (in relation to) a criminal organization. Subsequently in paragraph (2) it shall be stated: A criminal organization means a group (three or more) persons with a long-lasting hierarchical or personal relationship for the purpose of enriching themselves or supervising regions or markets, whether internal or foreign, in a way that violates laws such as violence, threats or corruption, and in promoting criminal activity also enter into a legitimate economy. 
nation's youth which is very endanger the life of the community, the nation, and the state so that Law Number 22 Year 1997 on Narcotics is no longer appropriate with the evolving situation and condition to overcome and eradicate the crime. Therefore, based on the provisions of Law No. 35 of 2009, that the enactment of Law Number 35 Year 2009, Law Number 22 Year 1997 is revoked and declared null and void.

\section{PROBLEMS}

Political Criminal Law of Narcotic Criminal Acts (Some Notes to Law No. 35 Year 2009)

\section{ANALYSIS AND DISSCUSSION Legal Protection Of Reports And Witnesses}

Since narcotics crime is part of organized crime, to reveal a case of narcotic crime, the role of the complainant and witness is very important. Therefore, there should be a legal guarantee that those who take part in helping to uncover a narcotic criminal act have at least a legal protection.

Unfortunately, in Law no. 35 of 2009, has not regulated the protection. As a comparison, the draft law on Prevention and Eradication of TPPU has arranged it into 2 (two) articles, namely Article 92 and Article 94. Each of thesearticles reads as follows:

\section{Article 92}

(1) Anyone who reports the alleged criminal act of money laundering shall be granted special protection by the State from the possibility of a threat to his or her own life, life and / or property, including his / her family

(2) Further provisions regarding the procedures for granting special protection as referred to in paragraph (1) shall be regulated by a Government Regulation

\section{Article 94}

(1) Everyone who gives testimony in the money laundering criminal examination shall be given special protection by the State from the possibility of threats that endanger himself, his soul, and / or his property, including his family.

(2) Further provisions regarding the procedures for granting special protection as referred to in paragraph (1) shall be regulated by a Government Regulation.

Article 92 regulates the protection of the complainants, and Article 94 provides for the protection of witnesses. Although, in the bill still need to be given a note such as: for a law there is harmonization with other laws, especially in the case of 
protection of Witness, in this case is Law no. 13 of 2006 on the Protection of Witnesses and Victims (State Gazette of the Year 2006 Number 64) dated August 11, 2006. Therefore, there needs to be a liaison between the Law on Prevention and Eradication of TPPU (when it has been law) with the Law No. 13 of 2006. Article to be made that, more or less reads as follows: the protection of money laundering crime witnesses is conducted based on Law no. 13 of 2006 on the Protection of Witnesses and Victims, except as provided in the Law on Prevention and Eradication of Money Laundering Crime. So, in particular in the case that has not been regulated by Law no. 13 of 2006 will be regulated in Law on Prevention and Eradication of TPPU.

Furthermore, in relation to the state's special protection obligations from possible threats to oneself, life, and / or property, including their families, whether given to the complainant or witness, should be examined more closely (although in Articles 92 and 94, respectively through paragraph (2) it states: further provisions on the procedure of granting special protection shall be regulated by a Government Regulation). However, it should be remembered that the protection is so far away, so the budget will be charged where. The goal, so do not let what has been arranged to be not functional.

What is mentioned, the bill of TPPU already there is anticipation effort in the future. And, in the case of the prevention of narcotics crimes that are part of organized crime (as well as money laundering), the reporters and witnesses should be interested in the Narcotics Law in the future. Even for the protection of witnesses, the UN Convention on Transnational Organized Crime (55/25), in Article 24 paragraph (1) Protection of witnesses, Each State Party shall take appropriate measures within its means to provideeffective protection from potential retaliation or intimidation for witnesses incriminal proceedings who give testimony concerning offences covered by thisConvention and, as appropriate, for their relatives and other persons close to them.

Therefore, the legal protection arrangements for such witnesses in the Narcotics Law need to be realized. However, since the Law on the Protection of Witness and Victim already exists, that is, as regulated in Law no. 13 of 2006, specifically for the legal protection of witnesses there should be a liaison between the Narcotics Law (when it has been 
updated) with Law no. 13 of 2006. Article to be made that, more or less reads thus: the protection of witnesses of narcotics crime carried out under Law no. 13 of 2006 on the Protection of Witnesses and Victims, unless specified in the Narcotics Law. So, in particular in the case that has not been regulated by Law no. 13 of 2006 will be governed by the Narcotics Law.

\section{The Responsibilities Of The Actors On The Victims Of Narcotic Crimanal Act}

The protection of victims is essentially an integral part of human rights issues, and the rights of victims themselves are an integral part of the concept of human rights. Therefore, if the human rights have been threatened or disturbed, it is necessary to guarantee legal protection against the victim.

Thus, the victim of the crime should be protected, because when the victim is still entitled to demand retaliation against the perpetrator, the victim can determine the size of the compensation. However, after all forms of retaliation and compensation are taken over by the state, the role of the victim is not considered anymore. Especially with the development of thinking in criminal law, where the need for guidance on the perpetrators in order to return to society. As a result, it has reduced the country's attention to the victims. ${ }^{4}$

Nowadays there has been a development of criminal law orientation, if the original criminal law is oriented to the crime, the target is the prevention of crime, then the offender is the target of treatment of offender, then the victim's target is treatment of victims. Attention to the victim, in accordance with the current developments in order for criminal law to eliminate the impression as if only pamper the offender rather than the victim.

In some countries, concern for the fate of victims has grown so convincingly, that in relation to the form of providing compensation to victims of crime. Attention to the fate of the victim in accordance with the wishes of the international community, marked by the convening of the UN Congress in Caracas, Venezuela, in 1980. The UN Commission on Crime Preventioan and Treatment of Offenders argued that at the UN VII Congress held in Milan in 1985 should address the issue of victims crime, which includes both conventional crime victims, such as violence against people as well as victims of various uses of power, economic and political power, organized crime,

\footnotetext{
4 Mardjono Reksodiputro. (1994). Kriminologi dan Sistem Peradilan Pidana. Pusat Pelayanan Keadilan dan Pengabdian Hukum (d/h Lembaga Kriminologi Universitas Indonesia). Jakarta. pg. 75-76.
} 
discrimination and exploitation, and paying particular attention particularly to vulnerable groups, such as children, women, and ethnic minorities. ${ }^{5}$

And, in accordance with the results of UN Congress VII of 1985 in Milan it was stated: the rights of victims should be seen as an integral part of the whole criminal justice system. In this regard, Joanna Shapland, et al ${ }^{6}$ once reminded that victims of crime have been forgotten by people from the criminal justice system. Lack of attention given to victims, it will undermine the workings of the criminal justice system.

Accordingly, J.J.M. van Dijk, et al ${ }^{7}$ wrote that in the first half of the 20th century criminal justice scarcely paid any attention to the position of the victim. Likewise with criminology, always directed to the perpetrator. Its development, only in the 60's emerged a number of attention to the injured party. With the intention, so that the suffering that the victim's burden is somewhat softened. Then, around 1980, in many countries, action groups that organized

\footnotetext{
5 Paul Zvonimir Separovic. (1985). Victimology Studies of Victims. Zagreb: Samobor-Novaki bb Pravni Fakultet. pg. 43, 425-426.

6 Joanna Shapland, Jon Willmoredan Peter Duff. (1985). Victims in the Criminal Justice System. England : Gower.pg. 1.

7 J. J. M. van Dijk, H.I. Sagel-Grande, dan L. G. Toornvliet. (1999). Kriminologi Aktual, Alih Bahasa P. Soemitro. Surakarta: Sebelas Maret University Press. pg. 289.
}

campaigns to treat victims better in the criminal justice system, and victimoriented criminologists, provided support for the effort.

The development of attention to the victims shows that the problem of the victims as part of the criminal justice system should have received attention. Responding to the outcome of the UN congress, the European Commission states that in an era of independence, justice and security within the framework of the European Union, there must be a guarantee of European citizens accessible in the criminal justice system. Therefore, individuals should be able to obtain adequate legal protection. This is important, because the rights of victims of crimes have been neglected for so long, and now it is time to pay more attention to the rights of victims. Efforts towards the protection of crime victims have actually been done since the early 1980's, in which the Council of Europe adopted several international instruments with the aim of improving the circumstances of victims of crime in the European Union. A further step forward, in several occasions has been discussed in the European Parliament. In 1998, the issue of protection of crime victims was discussed at the Council of the European Union, and the results of crime 
victims were included in the Action Plan on Freedom, Security and Justice.

The UN Declaration on Basic Principles of Justice for Victims of Crime and Abuse of Power itself has been adopted by the General Assembly Resolution 40/34, the General Assembly Resolution 40/34, and it reflects the collective will of the international community to restore a balance between rights fundamental suspects and perpetrators, and the rights and interests of victims. The existence of such declarations is based on a philosophical view that victims should be recognized and treated adequately on a humanitarian basis. Therefore, the victim is entitled to access to court mechanisms and to provide appropriate compensation for losses suffered. In addition, the victim is also entitled to receive adequate special assistance related to emotional trauma and other problems caused by the suffering that befalls the victim.

Caution or concern for victims of crime should not be confined to conventional crime victims (robbery, rape, theft, etc.), but should also include victims of non-conventional crimes, among them victims of trafficking in persons.

As noted above, the development of attention to crime victims is essentially an attempt to balance the fundamental rights of suspects and perpetrators, and the rights and interests of victims. To that end, the concept of protection of victims must be clear. In the sense of having to be determined in advance the direction or scope of such protection.

To develop a comprehensive concept of protection against victims, it should be related to the concept of punishment as presented by Barda Nawawi Arief ${ }^{8}$ that the concept of punishment must depart from a balance between two basic goals, namely the protection of society and the protection of individuals, resulting in the concept of Daad-daderStrafrecht. However, the protection of the individual in my opinion should also be expanded in scope, not only on the oriented offenders but also on the victims oriented. This victims oriented was extended again, not only oriented to potential victims, but also on the actual victims or direct victims.

Therefore, the concept of DaaddaderStrafrecht which is implemented in Article 11 of the 2008 Criminal Code Bill should be reviewed and developed into the Daad-dader-slachtoffer Strafrecht concept. Thus, the victim is no longer marginalized in criminal law. Therefore, balance and

8 Barda Nawawi Arief. (1996). Bunga Rampai Kebijakan Hukum Pidana, Bandung : Citra Aditya Bakti. pg. 98. 
equality need to be built in the future criminal law.

Protection of criminal law against the real victim or the direct victim, shall be charged to the perpetrator. In a sense, the offender of narcotics is responsible for the victim as a result of the offender's actions. In this context, the perpetrator must provide restitution to the victim. That, should be regulated in the Law on Narcotics. And, according to Steven Schafer, that the compensation to the victim should be the personal responsibility of the offender, the responsibility is basically also part of the correctional process. From this point of view, restitution is not only directed to the victim, but at the same time it also helps re-socialize and rehabilitate the perpetrator, and that is part of the punishment. ${ }^{9}$

Based on the above description, the question is whether Law no. 35 of 2009 has regulated the responsibility of the perpetrators concerned? Law no. 35 of 2009 only regulates Rehabilitation (Articles 54 through 59). While the responsibility of the perpetrator to the victim, not yet regulated.

As a comparable material, I refer to Law no. 21. In the Act, it has included

\footnotetext{
${ }^{9}$ M. Arief Amrullah. (2003). Politik Hukum Pidana Dalam Rangka Perlindungan Korban Kejahatan Ekonomi di Bidang Perbankan. Malang : Bayumedia Publishing. pg. 213.
}

legal protection against real or direct victims, that is, as implemented in Articles 43 to 55. Particularly regarding the responsibility of the perpetrators of victims of trafficking in persons is provided for in Article 48 to Article 50.

\section{Article 48}

(1) Every victim of a trafficking in persons or heirs shall be entitled to a restitution.

(2) The restitution as referred to in paragraph (1) shall be in the form of compensation for:

a. loss of wealth or income;

b. suffering;

c. fees for medical and / or psychological treatment measures; and / or

d. other losses suffered by victims as a result of trafficking.

(3) The restitution is granted and implied at the same time in the judgment of the court of criminal cases of trafficking in persons.

(4) The granting of restitution as referred to in paragraph (1) shall be implemented since the first court judgment is passed.

(5) Restitution as referred to in paragraph (4) may be entrusted in court where the case is terminated. 
(6) The granting of restitution shall be made within 14 (fourteen) days as from the date of announcement of the decision which has obtained permanent legal force.

(7) In the event that the offender is freed by the appeals or cassation court, the judge shall order in his decision that the deposited restitution be returned to the person concerned.

(8) The provision of restitution as referred to in paragraph (1) shall be implemented since the first court judgment is passed.

(9) Restitution as referred to in paragraph (4) may be deposited in court before the case is terminated.

(10) The granting of restitution shall be made within 14 (fourteen) days as from the date of announcement of the decision which has obtained permanent legal force.

(11) In the event that the offender is disconnected by the court of appeal or cassation, the judge shall order in his decision that the deposited restitution be returned to the person concerned.

\section{Article 49}

(1) The implementation of the provision of restitution shall be reported to the Chief Justice deciding the case, accompanied by evidence of the implementation of the grant of the restitution

(2) After the Chief Justice receives the proof as referred to in paragraph (1), the Chief Justice announces the implementation on the notice board of the court concerned.

(3) A copy of the evidence of the implementation of the provision of restitution as referred to in paragraph (1) shall be submitted by the Court to the victim or his heir.

\section{Article50}

(1) In the event that the implementation of the provision of restitution to the victim is not fulfilled until the deadline as referred to in Article 48 point (6) the victim or his heirs informs the court.

(2) The court as referred to in paragraph (1) shall give a written warning letter to the refund provider to immediately fulfill the 
obligation to provide restitution to the victim or his heir.

(3) In the event that the warning letter as referred to in paragraph (2) is not executed within 14 days, the court shall order the Prosecutor to confiscate the property of the convicted person and to auction the property for the payment of the restitution.

(4) If the perpetrator is unable to pay restitution, the perpetrator shall be subjected to a maximum of one year in jail.

(5) The court as referred to in paragraph (1) shall give a written warning letter to the refund provider to immediately fulfill the obligation to provide restitution to the victim or his heirs.

(6) In the event that the warning letter as referred to in paragraph (2) is not executed within 14 days, the court shall order the Public Prosecutor to confiscate the property of the convicted person and auction off the property for the payment of the restitution.

(7) If the perpetrator is unable to pay restitution, then the perpetrator shall be subjected to a maximum of one year in jail.
In Law no. 21 of 2007 has shown a lot of progress in terms of the responsibility of the perpetrator to the victim. There is a note: especially against the provisions of Article 50 paragraph (4) of Law no. 21 of 2007 there is a problem, because the one who can be sentenced to a criminal nature is a person or a human being, and in the context of the provisions of Article 50 paragraph (4) of Law no. 21 Year 2007 which can be criminalized is the management, but what about the legal entity or corporation? Whereas as already noted above, Article 1 number (4) of Law no. 21 of 2007 stipulates that what is meant by each person is not only individuals but also corporations. Thus, an impossibility if the corporation will be sentenced to a replacement cage penalty.

Thus, as written by J.J.M. van Dijk, et al. ${ }^{10}$ that in order to resolve the conflict between the perpetrator and the victim, the criminal constitutes assistance for the settlement of the conflict, because the criminal can be a satisfaction for the victim. The full resolution of the conflict between the offender and the victim in a criminal offense that results in a loss depends on the extent to which the loss is ultimately replaced or complied with.

10 J. J. M. van Dijk, H. I. Sagel-Grande, dan L.G. Toornvliet. (1999). Kriminologi Aktual. Op.cit 
Meanwhile, Law no. 35 of 2009 has not touched on the responsibility of the perpetrators to the victims as regulated in Law no. 21 of 2007. It should be Law no. 35 Year 2009 is already more advanced than the Law no. 21 Year 2007, as it was made later.

\section{Partnership In Municipal Infringement And Eradication Of Narcotics}

In Law no. 35 of 2009, the intended form of cooperation shall be inserted in Article 70 letter, not regulated in a separate Chapter. The sound of the provisions are: to conduct bilateral and multilateral cooperation, both regional and international, in order to prevent and combat the illicit trafficking of narcotics and precursors of narcotics.

That provision, too short and not detailed. Compare with the Bill on Prevention and Eradication of TPPU the arrangements are detailed and operational. This can be seen as follows:

\section{Article 96}

In conducting the prevention and eradication of money laundering crime, PPATK can cooperate with related parties, both in national and international scope.

\section{Article 97}
(1) The national cooperation undertaken by PPATK with related

parties is poured with or without formal cooperation form.

(2) Parties concerned as referred to in paragraph (1) shall be parties with direct or indirect linkages with the prevention and eradication of money laundering in Indonesia.

\section{Article 98}

(1) International cooperation shall be conducted by PPATK with similar institutions existing in other countries and international institutions related to the prevention and eradication of TPPU.

(2) International cooperation carried out by PPATK may be carried out in the form of formal cooperation or on the principle of reciprocity or reciprocity.

\section{Article 99}

(1) In order to prevent and combat the crime of money laundering, mutual assistance assistance in criminal matters with other countries through bilateral or multilateral forums in accordance with the provisions of prevailing laws and regulations shall apply.

(2) Mutual assistance cooperation as referred to in paragraph (1) may be implemented in the event that the said country has entered into 
mutual assistance cooperation agreement with the Republic of Indonesia or based on the principle of reciprocity.

\section{Article 100}

(1) To improve coordination among related institutions in the prevention and eradication of money laundering crimes, a National Coordinating Committee for the Prevention and Eradication of Money Laundering was established.

(2) Provisions concerning the establishment of the National Coordinating Committee for the Prevention and Eradication of Money Laundering Crime shall be regulated by a Presidential Regulation.

By citing the provisions set forth in Chapter $\mathrm{X}$ of the Draft Law on the Prevention and Eradication of the TPPU, it can be used as consideration in the framework of reform of Law no. 35 of 2009, so the task of National Narcotics Agency (BNN) can be more optimal and functional in the effort to overcome and eradicate Narcotics Crime.

If Law no. 35 of 2009 will be changed with a new formulation in the case of cooperation as stipulated in Article 96 of the Bill on the Prevention and Eradication of TPPU, the cooperation can be done by BNN with PPATK, namely in relation to the provisions of Article 137 of Law no. 35 of 2009 which reads :

Everyone who is:

a. placing, paying or spending, entrusting, exchanging, concealing or disguising, investing, storing, granting, inheriting, and / or transferring money, property and property or assets in the form of movable or immovable, tangible or intangible objects derived from a Narcotics Practice and / or criminal act of Narcotics Precursor, shall be subject to imprisonment of a maximum of 5 (five) years and a maximum of 15 (fifteen) years and a fine of at least Rp1,000,000,000.00 (one billion rupiah) and most many Rp10,000,000,000.00 (ten billion rupiah);

b. accepts placement, payment or expense, custody, exchange, concealment or investment disguise, deposits or transfers, grants, inheritance, property or money, property or assets whether in the form of movable or immovable, tangible or intangible material which is known to 
originate from a crime Narcotics and / or criminal acts of Narcotics Precursor, shall be subject to imprisonment of a minimum of 3 (three) years and a maximum of 10 (ten) years and a fine of at least Rp500,000,000.00 (five hundred million rupiah) and a maximum of Rp5,000,000 (five billion rupiah).

The provisions stipulated in Article 137 are closely related to the provisions of Article 2 of the Draft Law on the Prevention and Eradication of the TPPU, since narcotics is a criminal offense. Therefore, between the Narcotics Law and the Law on the Prevention and Eradication of the TPPU, there must be a provision that connects the two laws so that horizontal synchronization will occur.

\section{CONCLUSION}

Considering that a narcotics crime is a crime that could endanger the national interest, especially with the integration of a country's financial system into the world's financial system, it opens up opportunities for transnational crime, one of which is through the illicit trafficking of narcotics, will work well if it is only a separate country. Therefore, to reduce this problem requires an international approach. Such international cooperation is absolutely necessary both in exchange of information, as well as law enforcement, bilateral and multilateral agreements.

\section{BIBLIOGRAPHY}

Ambassador Wendy Chamberlin, Principal Deputy Assistant Secretary, Bureau for International Narcotics and Law Enforcement Affairs, U.S. Department of State, in Economic Perspectives, The Fight Against Money Laundering.

Barda Nawawi Arief. (1996). Bunga Rampai Kebijakan Hukum Pidana. Bandung: Citra Aditya Bakti.

Dokumen PBB No. E/CONF.88/2 tanggal 18 Agustus 1994

Mardjono Reksodiputro. (1994). Kriminologi dan Sistem Peradilan Pidana. Pusat Pelayanan Keadilan dan Pengabdian Hukum (d/h Lembaga Kriminologi Universitas Indonesia, Jakarta.

Paul Zvonimir Separovic. (1985). Victimology Studies of Victims, Samobor-Novaki bb Pravni Fakultet, Zagreb.

Joanna Shapland, Jon Willmoredan Peter Duff. (1985). Victims in the Criminal Justice System. England: Gower.

J.J.M. van Dijk, H.I. Sagel-Grande, dan L.G. Toornvliet. (1999). Kriminologi Aktual. Alih Bahasa P. Soemitro, Surakarta: Sebelas Maret University Press.

M. Arief Amrullah. (2003). Politik Hukum Pidana dalam rangka Perlindungan Korban Kejahatan Ekonomi di Bidang Perbankan. Malang: Bayumedia Publishing. 